\title{
Potency of Gaharu Leaves that Grows Naturally and Cultivately as Raw Material of Antioxidant-Rich Tea
}

\author{
Ridwanti Batubara ${ }^{1,2}$, Mimi Nurminah ${ }^{3}$, Tengku I. Hanum ${ }^{4}$, Surjanto $^{5}$ \\ \{ridwantibb@yahoo.com ${ }^{1,2}$, mimisinaga@yahoo.co.id ${ }^{3}$, ism4fzn@gmail.com ${ }^{4}$,yanto_juni@gmail.com ${ }^{5}$ \} \\ ${ }^{1}$ Faculty of Forestry, Universitas Sumatera Utara, Jl. Tridharma Ujung No. 1 Kampus \\ USU Medan 20155, North Sumatera, Indonesia \\ ${ }^{2}$ Center of Excelence for Natural Resources Based Technology, Universitas Sumatera Utara, \\ Medan, Indonesia \\ ${ }^{3}$ Faculty of Agriculture, Universitas Sumatera Utara, Jl. Prof A. Sofyan No. 3 Kampus USU \\ Medan 20155, Indonesia \\ ${ }^{4,5}$ Faculty of Pharmacy, Universitas Sumatera Utara, Jl. Tridharma No. 5 Kampus USU \\ Medan 20155, Indonesia
}

\begin{abstract}
Gaharu (agarwood) grows naturally in forest and cultivately by people in their farm area. The purposes of this research were to known the chemical compound and antioxidant activity of the gaharu leaf that grows naturally and cultivatelly. As 2 of gaharu leaves were identified, then processed into leaf simplicia, and extracted with $96 \%$ ethanol solvent. Gaharu extracted were tested through several testing such as; phytochemical screening, antioxidant activity, and hedonic method. Phytochemical screening showed no the different contain in gaharu leaves that naturally (Wikstroemia tenuiramis) or cultivately (Aquilaria malaccensis) grown, gaharu leaves positive contain flavonoid, glycosides, steroids/triterpenoids and tannins compounds. The results of antioxidant activity test showed that agarwood leaf extract that grows naturally and cultivately has $\mathrm{IC}_{50}$ value in 30.482 dan $41.130 \mu \mathrm{g} / \mathrm{ml}$ which very strong antioxidant activity category. Hedonic tests was on 3-4 scale with the like moderately category, feasible to be developed as an alternative tea.
\end{abstract}

Keywords: Agarwood, Antioxidant activity, Phytochemical screening

\section{Introduction}

Agarwood producing plants is one of the most important forest plants in Indonesia and in some countries such as India, Singapore, Malaysia, Japan, the Middle East and the United States [1]. Agarwood producing trees in Indonesia classified into three families: Thymelaceae, Euphorbiaceae and Fabaceae. Indonesia has at least 27 species of agarwood host from 33 species in Asia and spread in Sumatra, Borneo, Java, Nusa Tenggara, Sulawesi, Maluku, and Papua islands [2].

The type of host trees are widely known and cultivated Aquilaria crassna, A. beccariana, A. cumingiana, A. malaccensis, A. microcarpa, A. filaria and Gyrinops versteegii of family Thymelacea. In the natural habitat, agarwood grow associated at least with 13 species of trees, such as Alstonia angustifolia, Pometia pinnata, and Cananga odorata [3].

In 2002, Indonesia was able to produce agarwood reach 200 tonnes per year and selled around 70 percent in Singapore and to be exporter of agarwood in the world [4]. The growing 
value of agarwood to encourage interest in the industrialized countries to obtain aloes with selling price increases. The high price encourages community efforts to change the patterns of production, originally only utilize and or picked from trees that have died of natural production, became the cultivation of agarwood.

Agarwood leaves contained some chemical composition. They are 2-(2-phenylethyl) chromones, phenolic acids, steroids, fatty acids, benzophenones, xanthonoids, flavonoids, terpenoids, nucleosides and alkanes [5]. Moreover, the presence of these chemical compounds have the great potential used as antioxidants.

Research and utilization of agarwood leaf as a source of antioxidants to make it as tea products have been developed. This leaves utilization requires a series of studies to their future development. Fundamental researchneed to do is search on the chemical compounds that contained in the leaves of agarwood and antioxidant power and thus potentially to be used as a tea as a beverage that is favored by the public, both natural and cultivated grows. The type of agarwood that growing in North Sumatra is Aquilaria malaccensis Lamk (cultivated by community) and Wikstroemia tenuiramis (grows naturally).

\section{Research Methods}

\section{a. Location}

The sample used in this study was agarwood leaves from the identification result is a type of $W$. tenuiramis malaccensis Lamk. From Siantona villages which grows naturally, and Pekan Bahorok village A. malaccensis Lamk. which was cultivated by community. For phytochemical screening conducted at the Natural Material Chemistry Laboratory, Faculty of Mathematics and Natural Sciences and antioxidant testing were conducted at the Research Laboratory, Faculty of Pharmacy, while the determination of water content and extraction were conducted at Forest Product Technology Laboratory, Faculty of Forestry, Universitas Sumatera Utara.

\section{b. Procedure}

\section{i. Sample Collection}

The sample used in this study is agarwood leaves from the identification result is a type of A. malaccensis Lamk. and $W$. tenuiramis malaccensis.

\section{ii. Raw Material Preparation}

Gaharu leaves were cleaned of dirt with flowing water, then distribute on parchment paper until the water was absorbed. The plant materials were done by unnatural drying dried in the drying cupboard to dry and brittle the leaves with temperature $40^{\circ} \mathrm{C}-50^{\circ} \mathrm{C}$. The purpose was to get the simplicia that was not easily damaged, so it can be stored for a long time. The dried leaves were grinded using a blender and placed shielded from the sun before extraction and testing activities.

\section{iii. Determination of Water Content}

The determination of water content was done by Gravimetri method. 


\section{iv. $\quad$ Phytochemical Screening}

Phytochemical screening is a qualitative chemical examination of biologically active compounds presenting within simplicia and plant extracts, organic compounds. Therefore, screening is primarily intended for groups of organic compounds such as alkaloids, glycosides, flavonoids, steroids/terpenoids, tannins and saponins.

\section{v. Preparation of Ethanol Extract of The Leaves (A. malaccensis Lamk)}

The preparation of the extract was carried out maceration with $96 \%$ ethanol solvent, as much as $200 \mathrm{~g}$ of simplicia (dust) inserted into a glass vessel, poured with $1500 \mathrm{ml}$ of $96 \%$ ethanol, covered the glass, left for 5 days shielded from light and occasionally stirred. After 5 days, the mixture was filtered. The dregs were washed with $96 \%$ ethanol sufficiently to obtain $2000 \mathrm{ml}$, then removed in a closed vessel and left in place shielded from light for 2 days, then filtered. The maserate was concentrated using a rotary evaporator device at $40{ }^{\circ} \mathrm{C}$ until a concentrated maserate was obtained and then dried using a freeze dryer to obtain a dry extract.

\section{vi. Antioxidant Activity Test}

Antioxidant activity test of leaves water extract was evaluated by Free Radical Scavenger using DPPH as stated in Molyneux, 2004 with slight modification. Ascorbic acid was used as positive control. The measurement of absorbance was performed by UV-Vis spectrophotometer at $516 \mathrm{~nm}$ wavelength.

\section{vii. Hedonic Test}

The favorite test is also called a hedonic test. In a panelist hedonic test is asked for his personal response to preferences or the opposite of displeasure and suggest a level of fondness or also called a hedonic scale. The test was conducted in sensory (organoleptic) that is determined based on numerical scale. The test was given to 150 panelists of varying age (1750 years), sex and ethnic for tests on taste, aroma and color. The scale used in Table 1. The limit of rejection is the extent to which gaharu leaf tea is deemed unlike by the consumer to be at a numerical scale $\leq 3$.

Table 1. Hendonic scale and numeric scale

\begin{tabular}{ll}
\hline Hendonic Scale & Numeric Scale \\
\hline Like very much & 5 \\
Like a litle & 4 \\
Not sure & 3 \\
Dislike a little & 2 \\
Dislike very much & 1 \\
\hline
\end{tabular}

\section{Results And Discussions}

\section{a. Determination of Water Content}

Water content is closely related to the quality of simplicia. The detemination of water content is useful for presuming the durability or resilience of samples in storage.

The water content of agarwood leaves after drying with direct sunlight for three days and then drying in rack can be seen in Table 2. The result has fulfilled SNI requirement, that is not exceeding maximum $12 \%$. The result also meets the POM standard that the water content of the dried leaves did not exceed $10 \%[6]$. 
Table 2. Water content of agarwood leaves.

\begin{tabular}{ll}
\hline Gaharu Leaves & Water Content (\%) \\
\hline Naturally (Wikstroemia tenuiramis) & 5.33 \\
Cultivatelly (Aquilaria malaccensis) & 9.14 \\
\hline
\end{tabular}

In Table 2 the water content of simplicia 7.27 and $6.98 \%$. Drying under direct sunlight is usually fluctuating influenced by the daily temperature. To anticipate the uniform result, after three days of drying in the direct sunlight was followed by drying in the drying rack. Moisture content affected the quality of dry tea because it will affect the storage time. According to [7] that the factors that affect to the quality of food products are the water content in the product.

\section{b. Phytochemical Screening Results}

Gaharu (agarwood) leaves research was conducted to increase the benefits of the tree. Phytochemical screening is a preliminary study to find out secondary metabolites within plants. Phytochemical screening was conducted on fresh agarwood leaves simplicia dust to obtain information of secondary metabolite compounds class contained in the leaves. The results of phytochemical screening can be seen in Table 3 .

The results in Table 3 showed that the phytochemical screening test on agarwood leaves from two growing sites has a different content of chemical compounds. According [8] showed that the phytochemical screening of simplicia of agarwood leaf from Bahorok Langkat has a class of secondary metabolites, namely flavonoids, glycosides, tannins, and steroids / triterpenoids which have the potential as antioxidants. The diffrence of the chemical content of the agarwood leaves from Middle Tapanuli was caused by the tree grown naturally in nature that has still at the stage of growth poles, not yet formed their secondary metabolites.

The results obtained in Table 3 showed that phytochemical screening test have any differences in chemical compound group content on 2 growing sites of agarwood. Beside, Grynops versteegii also contains secondary metabolite compounds of flavonoids, terpenoids and phenolic compounds [9].

Table 3. Phytochemical screening of agarwood leaves.

\begin{tabular}{lll}
\hline Compounds & Gaharu Leaves & \\
& Wikstroemia tenuiramis & Aquilaria malaccensis \\
\hline Alkaloids & - & - \\
Flavonoids & - & - \\
Tannins & - & + \\
Saponins & + & + \\
Triterpenoids & + & - \\
\hline
\end{tabular}

The result of phytochemical screening gave the important information about the chemical compound contained by gaharu leaves. Screening the chemical compounds would facilitate the determination of usage, especially in the advanced utilization, mainly for treatment.

Cytotoxic activity depending on the dose observed in gaharu fraction shows the potential therapeutic usefulness of this medicinal plant against cervical cancer [10]. A. malaccensis leaves showed the ability to increase glucose uptake by increasing levels of GLUT4 in skeletal muscle. Further experiment is needed to explore this gaharu leaves as a strong antidiabetic [1]. 


\section{c. IC 50 (Inhibitory Concentration) Value of Tested Sample (Antioxidant Activity)}

The amount of antioxidant activity characterized by $\mathrm{IC}_{50}$ value was the concentration of the sample solution needed to inhibit $50 \%$ of $\mathrm{DPPH}$ free radical [11]. $\mathrm{IC}_{50}$ values were obtained based on the calculation of the linear regression equation obtained by plotting concentration of tested solution and DPPH scavenger percentage as a parameter of antioxidant activity, where the concentration of tested solution (ppm) as X-axis and the percentage of scavenger as Y-axis. The strength of antioxidant activity which categorized based on the $\mathrm{IC}_{50}$ value was referred to [12] which tabulated in Table 4.

Table 4. Strength category of antioxidant activity.

\begin{tabular}{ll}
\hline Category & $\begin{array}{l}\text { Concentrations } \\
(\mathrm{mcg} / \mathrm{ml})\end{array}$ \\
\hline Very strong & $<50$ \\
Strong & $50-100$ \\
Moderate & $101-150$ \\
Weak & $151-200$ \\
\hline
\end{tabular}

The capability of the tested sample in scavenge 1,1-diphenyl-2-picrylhidrazyl (DPPH) as free radicals in methanol solution with $\mathrm{IC}_{50}$ values (concentration of the sample which capable of scavenge free radicals by $50 \%$ ) was used as a parameter to determine the antioxidant activity of the sample [13]. $\mathrm{IC}_{50}$ value of the leaves ethanol extract was listed in Table 5.

Table 5. The $\mathrm{IC}_{50}$ value of agarwood leaves ethanol extract $(\mu \mathrm{g} / \mathrm{ml})$.

\begin{tabular}{ll}
\hline Gaharu Leaves Source & Antioxidant Activity \\
\hline Naturally (Wikstroemia tenuiramis) & 30.482 \\
Cultivatelly (Aquilaria malaccensis) & 41.130 \\
\hline
\end{tabular}

The strong or weak antioxidants are determined by several factors, one of which is the chemical composition. The chemical composition is also influenced by its habitat [14]. The main compounds that cause strong antioxidants are phenol group compounds, such as flavonoids. Ethanolic extract of the leaves have classes of secondary metabolites namely flavonoids, glycosides, tannins, and steroids/triterpenoids that potential as antioxidants.

The agarwood leaf tea has a very strong antioxidant content compared to others. The results of the analysis of the highest antioxidant activity from ten steeping types of Indonesian black tea quality were obtained by Dust I quality, with IC50 value of $97.00 \mu \mathrm{g} / \mathrm{ml}$, while for the lowest antioxidant activity with IC50 value of $178.56 \mu \mathrm{g} / \mathrm{ml}$ obtained by BTL quality [15]. This antioxidant content is an important thing that must be considered in processing the agarwood leaf tea.

According [16] explains that various plant commonly consumed in Indonesia contain antioxidants such as tannins [17], saponins and triterpenoids [18]. The research result of gaharu leaf tea has high antioxidant content that if consumed then be one source of antioxidant body.

\section{d. Hedonic Test}

This hedonic test was conducted to find out the respondent's opinion on the color, taste, and aroma of gaharu leaf tea. Test results can be seen on Table 6 . 
Table 6. Results of hedonic test survey level of community preferences to gaharu leaf tea.

\begin{tabular}{lccc}
\hline \multicolumn{1}{c}{ Gaharu Leaves } & Color & Taste & Aroma \\
\hline Wikstroemia tenuiramis & $3.66 \pm 0.96$ & $3.60 \pm 0.91$ & $3.54 \pm 0.84$ \\
Aquilaria malaccensis & $3.18 \pm 0.76$ & $3.40 \pm 0.90$ & $3.43 \pm 0.74$ \\
\hline
\end{tabular}

Note: Scale 1-5 : 1= Dislike Very Much, 2 = Dislike, $3=$ Not sure, $4=$ Like, $5=$ Like Very Much

Based on Table 6. It illustrates that the result of the respondent to gaharu leaf tea based on the type that gaharu leaf tea most preferred by community is gaharu leaf tea species W. tenuiramis Miq both in terms of color, aroma and taste with a favorite scale $>3$ (like). Based on this, it is known that the preferred level of the community prefers the tea, gaharu leaf $\mathrm{W}$. tenuiramis Miq, can be developed as an alternative tea rich in antioxidant.

\section{Conclusions}

In this work the gaharu leaf naturally and cultivated contained the same chemical compounds namely flavonoids, triterpenoids, and tannins. The results of antioxidant activity testing showed that gaharu leaves extract have IC50 value in 30,482 and $41,130 \mu \mathrm{g} / \mathrm{ml}$, respectively, with very strong antioxidant activity category which is feasible to be developed as an alternative tea rich in antioxidant.

Acknowledgement. The authors would like to acknowledge the Rector of Universitas Sumatera Utara, Medan, Indonesia, for financial support via Penelitian Dasar TALENTA project 2017 scheme.

\section{References}

[1] F. Said, M. T. Kamaluddin, and U. Sriwijaya.: International Journal of Health Sciences and Research Efficacy of the Aquilaria Malaccensis Leaves Active Fraction in Glucose Uptake in Skeletal Muscle on Diabetic Wistar Rats. (2016)

[2] M. Turjaman, A. Hidayat, and E. Santoso.: Agarwood. pp. 57-71 (2016)

[3] A. S. Khalil, M. Khan, KK. Taha, K.B. Abdallah.: Characterization of Methanolic Extracts of Agarwood Leaves. J. Appl. Ind. Sci. Vol. 1, no. 3, pp. 78-88 (2013)

[4] T. E. Komar, M. Wardani, F. I. Hardjanti, and N. Ramdhania.: In-Situ and Ex-Situ Conservation of Aquilaria and Gyrinops: A Review. Center for Conservation and Rehabilitation Research and Development in cooperation with International Tropical Timber Organization (ITTO)-CITES Phase II Project. (2014)

[5] A. Z. Adam, S. Y. Lee, and R. Mohamed.: Pharmacological properties of agarwood tea derived from Aquilaria (Thymelaeaceae) leaves: An emerging contemporary herbal drink. J. Herb. Med. Vol. 10, pp. 37-44 (2017)

[6] Ditjen POM.: Materia Medika Indonesia. Ministry of Health of the Republic of Indonesia. (1995)

[7] H. D. Isengard.: Water content, one of the most important properties of food. Food Control. Vol. 12, pp. 395-400 (2001)

[8] R. Batubara, T. I. Hanum, and Surjanto.: Phytochemical and tannin content in two species of agarwood leaves from Mandailing Natal Regency North Sumatera Province. AIP Conf. Proc. Vol. 2049 (2018)

[9] S. Hadi, H. Muliasari, N. S. Sukma, and P. E. W. Ratnaningsih.: Phytochemical 
Screening and Antibacterial Testing of Gaharu Trees (Gyrinops versteegii (Gilg.) Domke) from Lombok Island. Proc. 2nd Int. Semin. Chem., vol. 2011, pp. 79-82 (2011).

[10] Fatwati and Hidayat, Rachmat::Anti-Cancer Activity of Aquilaria Malacensis Leaves on Human Cervical Cancer Cells. European Journal of Pharmaceutical and Medical Research,. Vol 3, pp. 46-49 (2016).

[11] S. Aykul and E. Martinez-Hackert.: Determination of half-maximal inhibitory concentration using biosensor-based protein interaction analysis. Anal. Biochem. Vol. 508, pp. 97-103 (2016)

[12] R. Sumarny, S. Sofiah, and L. Nurhidayati.: Antioxidant activity of Mangosteen ( Garcinia mangostana L .) Fruit Rind Extract in Oral Solution Dosage Form. Int. Symp. Medicimal Plants Tradit. Med. Tawangmangu. Vol. 7, no. 1, pp. 1-7 (2014)

[13] H. Boutennoun et al:: In vitro cytotoxic and antioxidant activities of phenolic components of Algerian Achillea odorata leaves. Arab. J. Chem. Vol. 10, no. 3, pp. 403-409 (2017)

[14] J. Wang, S. Hu, S. Nie, Q. Yu, and M. Xie.: Reviews on Mechanisms of in Vitro Antioxidant Activity of Polysaccharides. Oxid. Med. Cell. Longev (2016)

[15] R. A. Gonbad, A. Afzan, E. Karimi, U. R. Sinniah, and M. K. Swamy.: Phytoconstituents and antioxidant properties among commercial tea (Camellia sinensis L.) clones of Iran. Electron. J. Biotechnol. Vol. 18, no. 6, pp. 433-438 (2015)

[16] N. Andarwulan, R. Batari, D. A. Sandrasari, B. Bolling, and H. Wijaya.: Flavonoid content and antioxidant activity of vegetables from Indonesia. Food Chem. Vol. 121, no. 4, pp. 1231-1235 (2010)

[17] B. Benzidia et al.: Chemical composition and antioxidant activity of tannins extract from green rind of Aloe vera (L.) Burm. F. J. King Saud Univ. - Sci. (2018)

[18] Y.-Y. Liu, Y.-N. Yang, Z.-M. Feng, J.-S. Jiang, and P.-C. Zhang.: Eight new triterpenoid saponins with antioxidant activity from the roots of Glycyrrhiza uralensis Fisch. Fitoterapia. Vol. 133, pp. 186-192 (2019) 